\title{
Access to Health Care by Migrants with Precarious Status During a Health Crisis: Some Insights from Portugal
}

\author{
Vera Lúcia Raposo ${ }^{1}$ (D) Teresa Violante ${ }^{2}$
}

Accepted: 18 March 2021 / Published online: 7 May 2021

(C) The Author(s), under exclusive licence to Springer Nature B.V. 2021

\begin{abstract}
In March 2020, the Portuguese Government issued a remarkable regulation by which irregular migrants who had previously started the regularization procedure were temporarily regularized and thus allowed full access to all social benefits, including healthcare. The Portuguese constitutional and legal framework is particularly generous regarding the right to healthcare to irregular migrants. Nevertheless, until now, several practical barriers prevented full access to healthcare services provided by the national health service, even in situations in which it was legally granted. This decision is not only remarkable in light of the fulfilling of migrants' rights to health, as imposed by international commitments assumed by, but also in view of the fight against COVID-19. The decision is grounded both on human rights and in public health reasons. The paper is divided in two main parts. In the first one, it analyzes national State obligations with regard to healthcare provision to migrants in irregular situation. In the second part, it analyzes the Portuguese solution, using this case study to discuss the possible mechanisms to comply with such obligations.
\end{abstract}

Keywords COVID-19 · Pandemic · Right to health · Irregular migrants · Public health · Portugal

\section{Introduction}

In the last couple of years, millions of migrants from Africa, Asia, and the Middle East entered the space of the European Union (EU). According to data from the International Organization from Migration (2019), currently there were around 272 millions of international migrants.

Vera Lúcia Raposo

vera@fd.uc.pt; vraposo@um.edu.mo

1 Faculty of Law, University of Macao, E32, Avenida da Universidade, Taipa, Macao, China

2 Friedrich-Alexander Universität Erlangen-Nürnberg, Erlangen, Germany 
Many of these people are currently in an illegal situation, either because they crossed the borders in violation of the law (clandestinely or with falsified documents) or because they remained in the EU without legal ground, for instance, after the visa's expiration of the denial of asylum request (Orrenius and Zavodny 2016). They are the so-called irregular migrants (Guild 2004).

Due to their (il)legal status, in most jurisdictions, irregular migrants do not have the same rights and guarantees as regular migrants (let alone nationals). This paper will deal with the right to health (Hayden 2012), in the particular aspect of access to health care (De Vito et al, 2015), specifically during a health crisis such as the COVID-19 pandemic, through the analysis of various scholarly works on internal human rights law. ${ }^{1}$

As a case study, the paper will use the case of Portugal, a particularly generous jurisdiction towards access to healthcare by irregular migrants. In March 2020, the Portuguese Government decided to temporarily regularize, for public health and humanitarian reasons, those who had already submitted applications for regularization.

Based on the Portuguese experience, the paper will then suggest some legal solutions to guarantee broad, safe, and efficient access to healthcare to this vulnerable population, with a particular focus on a public health crisis.

\section{Irregular Migrants, the Right to Health and Public Health}

\section{Irregular Migrants as a Vulnerable Population}

The concept of vulnerability in human rights is much discussed (Angeleri 2017; Peroni and Timmer 2013). In a sense, human beings are all vulnerable, as a part of our human nature (Turner 2006), but some are more vulnerable than others. These are the ones at particular risk of harm, i.e., the more exposed to human rights violations and discrimination (Angeleri 2017). The status of vulnerability demands specific attention to the satisfaction of basic rights (Da Lomba 2014), such as the right to health (Zaklaki 2019).

According to the common understanding of the United Nations (2014) and the InterAmerican Commission on Human Rights (2003), irregular migrants are vulnerable populations. This is an idea shared by many authors (Hinterberger 2019). Desmond (2016, p. 248), for instance, talks about the "inherent vulnerability of irregular migrants."

Nonetheless, it is a contested qualification. The European Court of Human Rights (ECtHR) seems to adopt a more restrictive perspective by stating that irregular migrants are not, per se, vulnerable populations, unless there is an additional ground for vulnerability, such as "fragile health," or special conditions such as being asylumseekers, ${ }^{2}$ or families with children. ${ }^{3}$ Accordingly, the ECtHR does not consider the

\footnotetext{
1 'As of 22 April 2020, migrants accounted for at least 10 per cent of the population in 10 of the 15 countries with the highest number of COVID-19 case' (Migration Data Portal 2020).

2 M.S.S. v. Belgium and Greece No 30696/09, 21 January 2011, at par. 251.

${ }^{3}$ Tarakhel V. Switzerland No 29217/12, 4 November 2014, at par. 99.
} 
absence of medical protection for irregular migrants as a degrading treatment in light of Article 3 of the European Convention of Human Rights (ECHR), ${ }^{4}$ except when particular situations make them especially vulnerable.

\section{Access to Healthcare by Migrants in Irregular Situation}

Vulnerable populations face special challenges in what regards their access to health care. Barriers in access to healthcare include economic constrictions, bureaucratic and legal barriers in using healthcare services (especially public funded ones), lower rates of affiliation with a regular care provider, difficulties in communication, and unmet health needs (Corscadden, L., Levesque, J.F., Lewis, V. et al. 2018).

In many jurisdictions, irregular migrants are not eligible to receive welfare benefits, including healthcare (unless they are refugees or unaccompanied children), for whom some social benefits are generally available (European Union Agency for Fundamental Rights 2011; World Health Organization 2018b). Irregular migrants' access to healthcare is regulated in different ways all around the world, but there is a common point: laws tend to impose varying degrees of limitations. Usually, the Portuguese national health service only provides emergency treatments (at no cost or a symbolic cost). Apart from those exceptional cases, the only option is, therefore, to use private healthcare facilities, but the cost becomes an insurmountable obstacle. Most of them cannot afford health insurance schemes; neither can they pay for healthcare from their own pockets. NGOs provide some medical services, but NGOs in general usually just cover very basic needs (Jackson et al. 2019). So, they are basically deprived of any medical assistance.

Money is not the only hindrance. Difficulties in communicating and unawareness regarding how the health system works prevent irregular migrants from using the (limited) health services options offered to them.

Limitations on access to health care are especially troubling since migrants tend to be particularly susceptible to health risks (Guadagno 2020; Jackson et al. 2019; Liem et al. 2020) (a feature that reinforces their vulnerability). Many have not completed the vaccination program (some might not be vaccinated at all), and several suffer from chronic diseases. Their living conditions (poor food, unhealthy and unhygienic housing) make them more exposed to health hazards. Those circumstances hardly allow them to comply with the preventive measures eventually recommended by the health authorities, and they might not even be able to understand instructions due to the lack of language proficiency. Last, but not least, because of their unauthorized status, they might refrain from looking for help even when seriously sick, for fear of stigmatization, xenophobia (Devakumar et al. 2020), arrests, and even deportation (D'Ignoti 2020; Kuehne et al. 2015; Poduval et al. 2015).

\section{Challenges Faced by Irregular Migrants to Cope with COVID-19}

During the COVID-19 pandemic, several measures were issued by health authorities to cope with the new coronavirus. However, the particular conditions of irregular migrants

\footnotetext{
4 'Article 3 does not place an obligation on the Contracting State to alleviate such disparities through the provision of free and unlimited health care to all aliens without a right to stay within its jurisdiction' (Hunde v. The Netherlands No 17931/16, 5 July 2016, at par. 54).
} 
make it challenging to benefit and to comply with many of them (Guadagno 2020; Liem et al. 2020).

For a start, home confinement. The goal is to avoid gatherings and to keep people in a place where they feel safe, and do not have to contact many people. Some of these migrants live on the streets, so, like any other homeless people, they do not have a home where to stay confined (Accornero et al. 2020). But even for the ones that do have a "home" (let's say, a roof), this measure might not lead to the desired results because they usually live in crowded places, where the protection from human contact is utopic. For this very same reason, it is also difficult for them to follow the hygiene measures promoted during the pandemic. Taking baths or even washing hands might be an arduous task when the restrooms have poor conditions and are shared by too many people.

Restricting social contact is a "luxury" that not everyone can afford. Irregular migrants cannot (legally) work, but despite the legal ban, many of them are forced to leave their place to make a living, otherwise they might lose income or even their work. They have precarious job situations, and the kind of activities they perform (manual labor) is not compatible with telework. As pointed by Dewhurst (2013), they have a very low earning coming from illegal work, they are an easy target for exploitation, and they are hardly protected by labor regulations. Frequently their work commute requires the use of, eventually, very crowded, public transports (irregular migrants do not have private transportation). In most cases, there is no proper protective equipment (facemasks, gloves) to work. All these features carry an additional risk of infection.

Access to health care is extremely difficult for irregular migrants. ${ }^{5}$ As referred to above, the national health service is out of their range, except for minimal situations. Many of them depend on assistance from NGOs or other organizations, which during a health crisis, might be suspended or limited as their precarious financial situation prevents them from using private facilities. The national health service remains the only realistic option to receive healthcare. Even if the provision of medical services is free of charge, it might not solve all the issues. Since the new coronavirus spreads easily, and in order to avoid people going to hospitals as foci of infection, many healthcare facilities are providing several types of services by using telemedicine. However, for people that do not master the language, distance communication might be challenging. Deprived of computers, smart phones, and even the internet, telephone consultations are the only option. Still, many of them are not able to understand what is being said or are unaware of such mechanisms (ANSA 2020).

Furthermore, during the pandemic, most of them see their economic situation worsen: dismissal without any compensation or any other social protection, elimination, or restriction of social aid from churches or NGOs. Even when governments create special assistance schemes (vouchers, subsidies, special conditions to pay rent), those are only provided to legal residents.

\footnotetext{
${ }_{5}^{5}$ People from ethnic minorities are clearly overrepresented among the ones identified as infected with COVID-19 and admitted in hospitals (Intensive Care National Audit and Research Centre 2020). Obviously, this is not because they do not get sick, but because they don't look for medical assistance, for fear of legal repercussions and/or for lack of economic resources.
} 
Even more hazardous is the situation of irregular migrants under detention. The immigration detention centers hardly fill the minimum conditions during a pandemic: health care services are quite restricted, facilities are overcrowded and unsanitary, and hygiene products are reduced (International Organization for Migration 2016). However, their right to health is not suspended when detained, ${ }^{6}$ and ultimately it may impose their release. The EU Return Directive ${ }^{7}$ allows detention to be kept up to 18 months (Articles 15/5 and 15/6 of the EU Return Directive). Still, it clarifies that

[w] hen it appears that a reasonable prospect of removal no longer exists for legal or other considerations or the conditions laid down in paragraph 1 no longer exist, detention ceases to be justified, and the person concerned shall be released immediately (Article 15/4 of the EU Return Directive).

Both the United Nations (Subcommittee on Prevention of Torture and Other Cruel, Inhuman or Degrading Treatment or Punishment 2020) and the Council of Europe (Council of Europe 2020; European Committee for the Prevention of Torture and Inhuman or Degrading Treatment or Punishment 2020) called for the release of irregular migrants, and several States (Belgium, Spain, the Netherlands, and the UK) responded to the call. Nonetheless, merely releasing these migrants, without providing the necessary conditions to cope with the pandemic (shelter, healthcare) does not serve them much.

\section{International Human Rights Obligations Regarding the Right to Health}

International bodies had enacted different calls encouraging states to enlarge the subjective scope of healthcare policies. The European institutions have issued several documents in this regard (European Commission 2009). The European Parliament (European Parliament 2011) expressly referred the situation of irregular migrants. The World Health Organization (WHO) had been advocating the need to extend health coverage to everyone, as a way to comply with State obligations under international law (Ghebreyesus 2017). Nonetheless, the position of the WHO in this regard is dubious, since it has recognized to member states the power to discriminate against immigrants. The UN's Global Compact for Safe, Orderly and Regular Migration (World Health Organization 2018a) grants to Member States the power to discriminate against irregular migrants: "Within their sovereign jurisdiction, States may distinguish between regular and irregular migration status, including as they determine their legislative and policy measures for the implementation of the Global Compact" (Recital 15).

However, there is a gap between rights in theory and rights in practice for immigrants (Larking, 2016). Moreover, as most social and economic rights, the right to

\footnotetext{
$\overline{6}$ 'International standards highlight that states should ensure that persons in detention have access to the same standard of health care as is available in the community, and that this applies to all persons regardless of citizenship, nationality or migration status' (Office of the High Commissioner for Human Rights and World Health Organization 2020: 4)

${ }^{7}$ Directive 2008/115/EC of the European Parliament and of the COUNCIL of 16 December 2008 on common standards and procedures in Member States for returning illegally staying third-country nationals.
} 
health is mostly taken as a guiding principle rather than an enforceable norm, and its concretization raises difficulties (Angeleri 2017).

The right to health is mentioned in the preamble of the WHO Constitution of 1946 (World Health Organization 1946) and in Article 25 of the Universal Declaration of Human Rights. Even more explicitly, the International Covenant on Economic, Social and Cultural Rights (ICESCR) very clearly states in its Article 12/1: "The States Parties to the present Covenant recognize the right of everyone to the enjoyment of the highest attainable standard of physical and mental health." The norm especially mentions "(c) the prevention, treatment, and control of epidemic, endemic, occupational, and other diseases" and "(d) the creation of conditions which would assure to all medical service and medical attention in the event of sickness." The Committee on Economic, Social and Cultural Rights (CESCR) has played an essential role in clarifying the content of the basic state obligations necessary to guarantee the right to health and among them identified the obligation "[ $\mathrm{t}] \mathrm{o}$ take measures to prevent, treat, and control epidemic and endemic diseases" as a core obligation (paragraph 44/c) (Committee on Economic, Social and Cultural Rights 2000). Moreover, based on Article 12 ICESCR, the CESCR has been advocating that States are under the obligation to respect the right to health by, inter alia, refraining from denying or limiting equal access for all persons, including [. . .] asylum-seekers and illegal migrants, to preventive, curative, and palliative health services (paragraph 34).

The Council of Europe also has some work done in this domain. Article 2 of the ECHR proclaims the right to life, which has been used in claims about health care services. ${ }^{8}$ However, whenever these claims deal with the allocation of health resources, their success is limited by the very interpretation the ECtHR makes of this norm, as preventing understandings that "impose an impossible or disproportionate burden on the authorities," as stated in Osman v. The UK. Thus, Article 2 ends up having a narrow effect in this regard.

The European Social Charter (ESC) is more incisive. Article 11 of the ESC, on "the right to protection of health," expressly refers to the prevention of epidemics (n. 3), , $^{9}$ and Article 13 provides for the right to medical assistance. According to the European Committee of Social Rights, that oversees the Charter, among the state obligations derived from these norms is the provision of special measures to safeguard the health of the most vulnerable ones and (even though a less explicit obligation) the duty to meet the costs of healthcare provision (McHale 2010). Based on these provisions, the European Union Agency for Fundamental Rights concluded that "States have an obligation to prevent epidemics and provide the means of combatting epidemic diseases" (European Union Agency for Fundamental Rights 2020: 8). It can be argued, though, that the ESC does not cover migrants in irregular situation since its personal scope is limited to "foreigners only in so far as they are nationals of other Parties lawfully resident or working regularly within the territory of the Party concerned" (Appendix of the ESC, Recital 1). Nonetheless, the case law

\footnotetext{
${ }^{8}$ See, for instance, Osman v. The United Kingdom No 23452/94, 1998.

9 This duty to prevent epidemics must also encompass the duty to prevent the progression of the epidemic, which obviously entails the provision of adequate healthcare measures to everyone.
} 
of the European Committee on Social Rights seems to enlarge that scope, especially in what regards migrant children (Merlino and Parkin 2012: 7), as demonstrated by FIDH v. France ${ }^{10}$ and Defence for Children International v. the Netherlands. ${ }^{11}$

The most recent rights document prepared under the umbrella of the Council of Europe is the Convention on Human Rights and Biomedicine, whose Article 1 imposes the safeguard of human dignity, which shall include the satisfaction of (at least) basic health needs. ${ }^{12}$

In what regards European law, several norms of the European Union's Charter of Fundamental Rights (CFR) can be used to ground the State's duty to provide healthcare to irregular migrants. ${ }^{13}$ Article 1 of the CFR, stating the inviolability of human dignity, might be a possible ground (Čelkis and Venckiene 2014), even though human dignity might be too vague to play the role. Article 4 of the CFR forbids torture and inhuman and degrading treatment or punishment. Some suggest an interpretation of this norm in light of which the denial of medical treatments can be qualified as inhuman and degrading treatment (McHale 2010) (although this same interpretation has not been successful regarding an equivalent norm of the ECHR) (McHale 2010). Article 20 of the CFR declares the equality of everyone before the law, and Article 21 of the CFR forbids several grounds for discrimination: sex, race, color, ethnic or social origin, genetic features, language, religion, or belief. By far, the most explicit norm is Article 35 of the CFR, on the chapter about solidarity, stating the right to healthcare. The norm very clearly entitles people ("Everyone," not only EU nationals) with this right (McHale 2010), as it was expressly recognized by the Advocate-General in Stamatelaki:

\footnotetext{
${ }^{10}$ International Federation for Human Rights (FIDH) v. France, Collective Complaint No. 14/2003, Decision on the merits of 8 September 2004, at https://hudoc.esc.coe.int/eng/\#\{\%22sort\%22: [\%22ESCPublicationDate\%20Descending\%22],\%22ESCDcIdentifier\%22:[\%22cc-14-2003-dmerits-en\%22] \} (accessed in 28 December 2020): 'legislation or practice which denies entitlement to medical assistance to foreign nationals, within the territory of a State Party, even if they are there illegally, is contrary to the Charter' (Recital 32).

${ }^{11}$ Defence for Children International v. the Netherlands, Complaint No 47/2008, Decision on the merits of 20 October 2009, https://hudoc.esc.coe.int/eng/\# \{\%22sort\%22:[\%22ESCPublicationDate\%20Descending\%22] ,\%22ESCDcIdentifier\%22:[\%22cc-47-2008-dmerits-en\%22]\} (accessed in 28 December 2020): 'states parties are required, under Article 31.2 of the revised Charter, to provide adequate shelter to children unlawfully present in their territory for as long as they are in their jurisdiction' (Recital 64).

12 The International Convention on the Protection of the Rights of All Migrant Workers and Members of their Families. New York, 18 December 1990 also guarantees the right to medical care, but only to regular migrants.

13 The EU Return Directive grounds access to emergency health care and essential treatment of illness to migrants during the period for voluntary departure or removal postponement (Article 14(1)(b)). This document also grants access to emergency health care to migrants who are subject to a refusal of entry according to Article 13 of the Schengen Borders Code, or who are intercepted on an irregular crossing of the external border of a Member State (Articles 4(4)(a) and 2(2)(a)). In any case emergency treatment must not be subject to the payment of fees. See European Commission, Return Handbook, C(2017) 6505, at 75. This document also details thoroughly the right to health care of irregular migrants who are detained for the purpose of return or removal procedures. Arguing that the Return Directive grants access to social rights and health care beyond these provisions, see Hinterberger and Klemmer, 2020.
} 
This right is perceived as a personal entitlement unconnected to a person's relationship with social security and the Court of Justice cannot overlook that aspect. $^{14}$

However, the definition of who can have access to health care and in which conditions depends solely on Member States since the powers and competences of the EU in this domain are quite restricted and always subsidiary (Raposo 2020a). So, in the end, Member States keep in their hands the power to define the recipients of this right. ${ }^{15}$ Although domestic decisions can ultimately condition several EU policies (Platform for International Cooperation on Undocumented Migrants 2015) and State obligations in light of the treaties ${ }^{16}$; and in spite of the principles of universality, equality and solidarity that coin EU law (Terminsk 2018), the fact is that Member States are not obliged under the CFR to equate irregular migrants to national citizens in what regards healthcare (Lorena and Foulvia 2016; Terminsk 2018).

In light of the abovementioned provisions, the denial to guarantee healthcare to irregular migrants constitutes unlawful discrimination (Chetail 2019) and a violation of human rights obligations (Onarheim et al. 2018; Platform for International Cooperation on Undocumented Migrants 2014), but so far they hardly led to legal liability.

\section{Allocation of Scarce Resources and Economic Savings}

The provision of health care, at no cost or at reduced cost, to migrants in irregulating situations has always raised controversy (Zaklaki 2019). It has been argued that this is merely a form of health tourism that should not be supported by national taxpayers (Milne 2016) and that only the latter, who contributed to the creation of the financing fund, should benefit from it (Department of Health 2017). The claim is that the provision of health services to migrants deprives the residents of the health care they are entitled to, based on their legal status. In moments of economic crisis, such as the one we are living, this argumentation is very seductive, and it has been especially supported by right wing parties all over Europe (Gottlieb et al. 2020).

The dichotomy health versus money is a classic one. On the one hand, the right to health (and other human rights) require their satisfaction. Still, on the other hand, the realization of this right involves public expenditure and complex assessments regarding the allocation of scarce resources (World Health Organization 2014a). The satisfaction of the right to health of an individual might be denied based on the satisfaction of the right to health of another person. If one of them is an irregular migrant, his/her irregular status might jeopardize his/her chances in this assessment. This conflict, however, might be more apparent than real.

First, because the pursuit of health goes hand in hand with financial savings. If proper healthcare (preventive and follow-up measures) is not provided to irregular

\footnotetext{
$\overline{14}$ Opinion of Advocate-General Ruiz-Jarabo Colomer, in Aikaterini Stamatelaki v. NPDD Organismos Asfaliseos Eleftheron Epangelmation- Case C-444/05, Stamatelaki [2007] ECR I-3185, delivered on 11 January 2007.

${ }^{15}$ Moreover, Member States are only bound by the rights proclaimed in the ECFR when they are 'implementing Union law' (Article 51/1 ECFR).

${ }^{16}$ Article 168 TFEU: 'A high level of human health protection shall be ensured in the definition and implementation of all Union policies and activities'.
} 
migrants, health conditions that could be easily (and cheaply) solved might become severe health problems, requiring more costly treatments. Therefore, what could be seen prima facie as an added cost, ends up being a saving (Raghupathi and Raghupathi 2020; World Health Organization 2014b).

Secondly, because depriving irregular migrants of accessing healthcare might become a risk to every community member in this particular scenario since unprotected groups of people easily become clusters of infection. This conclusion is connected with the very nature of the medical condition at stake. Unlike other diseases, the kind of infectious diseases that lead to a pandemic is easily transmissible. It is not only a matter of individual health but also of public health (the community's health). Thus, the satisfaction of the right to health of nationals and regular residents imposes the equal provision of healthcare to irregular migrants. Even if governments are solely concerned with the protection of some individuals (assuming this would be legitimate, which is not in light of international human rights obligations), they still need to provide healthcare to all individuals, including irregular migrants, otherwise, the pandemic will spread (and thus costs will increase). The success of the fight against the pandemic depends on the fact that everyone receives decent medical assistance, in particular the most vulnerable ones. A chain is as strong as its weakest link.

\section{An Insight from Portugal}

In 2018, the Portuguese Immigration Services (hereinafter, SEF) identified 1.839 irregular citizens from third countries in Portugal, representing $9 \%$ of all thirdcountry migrants (Serviço de Estrangeiros e Fronteiras 2018). ${ }^{17}$ To fully grasp the importance and meaning of the Portuguese Government's decision to provisionally regularize certain migrants during the Covid-19 pandemic, to grant them access to certain basic rights, it is important to first determine the level of protection they would be entitled to in principle.

It is also important to take stock of the difficulties irregular migrants generally experience in the implementation and effective exercise of the rights legally granted to them in the Portuguese jurisdiction. With a generous constitutional and legal framework regarding the protection of migrants in general, they face considerable obstacles in practice. These obstacles are diverse and include bureaucratic difficulties and administrative practices that breach constitutional and legal entitlements.

Moreover, recent amendments to the Immigration and Asylum Acts ${ }^{18}$ contributed to additional stress on the Immigration Services that persistently fail to meet legal deadlines in processing requests and to granting documentation, leaving these individuals in an undocumented limbo that further fragilizes their situation.

\footnotetext{
${ }^{17}$ Third-country nationals refer to individuals coming from outside the EU, the EEA, Switzerland or any other country with which Portugal had bilateral agreements. In health matters, Portugal has entered into several bilateral agreements with Portuguese-speaking countries.

${ }^{18}$ Respectively, Law 7/2008, of June 30, amended by Law 26/2014, of May 5, and Law 29/2012, of August 9 , amended by Laws 56/2015, of June 23, 63/2015, of June 30,59/2017, of July 31, 102/2017, of August 28, 26/ 2018, of July 5, and 28/2019, of March 29.
} 


\section{The Constitutional and Legal Framework}

Under the Portuguese Constitution (hereinafter, PC), regular and irregular migrants fall under the category of "foreigners" and "stateless people," who benefit from a generous, protective framework.

Foreigners and stateless individuals who find themselves or reside in the national territory enjoy the same rights and are subject to the same duties as Portuguese citizens (Article 15/1 PC). As a rule, these individuals are assimilated to national citizens in terms of rights and duties. The far-reaching assimilation clause must be read considering other constitutional provisions, particularly the constitutional mandate of openness towards international human rights law. First, there is a constitutional provision that opens the national constitutional order to other fundamental rights not expressly enshrined therein, including those enshrined in applicable international law (Article 16/1 PC). Second, the constitutional and legal provisions on fundamental rights must be interpreted and integrated under the UDHR (Article 16/2). International human rights can thus be applied both as a source of law and as an interpretation tool. Moreover, the Fundamental Law is based on the principle of human dignity (Article $1 \mathrm{PC}$ ), which stands as the cornerstone of the legal and political order and oversees the interpretation of constitutional provisions, particularly those concerning fundamental rights.

Another aspect that singularizes the Portuguese constitutional acquis is its extensive and detailed bill of rights, comprising a long list of civil and political rights, as well as economic, social, and cultural rights. Under its dualistic character - that is reminiscent of historical tensions during the drafting process - the bill of rights pays tribute to both the democratic liberal and the socialist traditions, conveying a synthesis of the influence of both the International Covenant on Civil and Political Rights and the ICESCR.

In principle, the constitutional and legal rights also cover foreigners and stateless people. This is called the principle of assimilation, which works as a general clause unless otherwise stated or inferred. The exclusion of migrants from the enjoyment of fundamental rights is the exception and not the rule, subject to the express or implicit constitutional reservation of certain rights to nationals and specific categories of foreigners (EU citizens, Portuguese-speaking nationals, and cases covered by reciprocity clauses). Moreover, the assimilation clause assigns rights to these individuals but does not allow modulation of their normative content, unless there is a valid justification to support the unequal treatment (Silva 2010). In fact, according to Article 13(2) $\mathrm{PC}$, differentiations on the basis of national origin are prohibited and constitute suspicious discrimination clauses.

The constitutional terminology varies between offering protection to "citizens," "individuals" or "everyone." As it is generally accepted by the literature (Silva 2004; Canotilho and Moreira 2007; Silva 2010; Gil 2017), these semantic indications are not decisive to determine the right holders.

The most contested issue involving the assimilation regards its subjective scope. It is widely discussed whether the assimilation clause applies to every foreigner and the stateless person or only to those who have legally entered the national territory or who legally stay there. There are good arguments to claim that the distinction between legal and illegal entry cannot ground a differentiated treatment of individuals and is not legitimately covered by the assimilation discipline (Freitas 2009, Gil 2017; against, Silva 2010). Most significantly, the assimilation principle is drafted in broadly generous 
terms and defines its exceptions in considerable detail (Article 15/2-5 PC). Nothing in the wording of this clause, nor any of the other relevant constitutional provisions (significantly: the equality and universality principles in respect to fundamental rights) points to a narrow reading that would limit assimilation to those individuals who have legally entered the national territory. In a recent case, the Constitutional Court affirmed that the principle of assimilation applies to all foreigners, and not only to those legally resident, at least as regards a "core set of (universal) rights from a constitutional or international source" (Judgment 296/2015).

However, the regulatory framework sets forth several derogations to the general equalization between national and non-national citizens that seriously affect irregular migrants.

One of these cases concerns access to the right to health. The PC enshrines a universal, general, and tendentially free right to health, which is primarily guaranteed through the implementation, incumbent on the State, of a national health service. ${ }^{19}$ To fulfill this mandate, the Government may act directly as a provider of healthcare or, subsidiarily and with a limited duration, through private providers.

As a rule, and since the enactment of the new Healthcare Basic Law, in 2019, both regular and irregular migrants are also beneficiaries of the national health service, following the applicable legal framework. ${ }^{20}$ The clarification that both regular and irregular migrants are entitled to accede the national health service was thus introduced in 2019. The previous wording only referred to foreigners, under conditions of reciprocity, and stateless people, both residing in Portugal (Base XXV(3) of Law 47/ 90, of August 24). This change in the legal text points to a more generous reading of the right of access of migrants to the national health service, whether regular or irregular.

The Strategic Plan for Migration had already ${ }^{21}$ evidenced a generous reading. This policy document, approved in 2015, called for an "[e]xplanation of the application of the regulatory framework concerning the access of migrants with irregular documentation to the national health service." This measure, however, was never implemented. By recognizing this duty to "explain," the Strategic Plan for Migration acknowledged that access of irregular migrants to the national health service demanded clarity. The policy action does not concern the need to develop a new policy or to draw new measures, but rather to simply "explain" how the access of undocumented migrants to the national health service is regulated. The Plan also contemplated the need to implement and monitor the "Reception Manual at the Foreign Citizens Health System"

\footnotetext{
${ }^{19}$ The health system comprises a tax-financed national health system, special public and private insurance schemes for certain professions (health subsystems), and private voluntary health insurance. These systems are co-existing and overlapping. The basic benefit packed provided by the national health service includes primary care and specialized hospital care. Dental consultations, diagnostic services, renal dialysis and rehabilitation are usually delivered by private providers although there is public funding available.

${ }^{20}$ Base XXI, par. 2, of Law 25/2019, of September 4. This provision also encompasses EU citizens who reside in Portugal permanently or temporarily, nationals from other assimilated countries, asylum-seekers and regular migrants. All these individuals benefit from healthcare under the same conditions applicable to national individuals. The asylum law explicitly guarantees asylum-seekers and international protection applicants, as well as the members of their household, the right to access the national health service and therefore benefit from healthcare and medication assistance (Article 52 of Law 27/2008, of June 30, amended by Law 26/2014, of May 5). See also Ordinance 30/2001, January 17 and Ordinance 1043/2008, September 15.

${ }^{21}$ The Plan was approved by Resolution of the Council of Ministers 12-B/2015.
} 
(Direção-Geral de Saúde 2013), which was adopted in 2013 but lacked (and still lacks) consistent implementation throughout the national health service units.

The applicable framework, however, has not been amended, and access to healthcare remains subject to several restrictions and conditions. To understand the relevance of the new provisional regularization process, we will now determine how the access to healthcare of irregular migrants is generally regulated and implemented in light of the legal and regulatory regimes which precede the current Basic Health Law.

Theoretically, no one can be denied medical care on the grounds of economic insufficiency. That results directly from Articles 13 and 64 PC, and there is an express legal provision exempting the beneficiaries of national health service from payment of moderating fees in case of economic insufficiency. ${ }^{22}$ Being a beneficiary depends on holding a right to access the national health service.

In principle, access by migrants to health care in Portugal is more generous than in other European countries (Simões et al. 2017). Considering the constitutional framework and the recent change introduced by the Basic Health Law, irregular migrants should be entitled to access the national health service. However, as the regulatory health agency and previous research have consistently reported, there are empirical constraints on effective access by foreigners to health services (Dias et al. 2011).

\section{The Regulatory Framework}

These constraints can be partly explained by the ambiguous legal and regulatory framework governing the access of irregular and undocumented migrants to health care. This is caused by the fact that the regime is detailed in several separate administrative documents and guidelines, whose interpretation and systematization are challenging to achieve coherently. Note that, in the Portuguese framework, we should distinguish between irregular migrants who hold a document (either a permit or asylum request of an official proof of residency), and genuinely undocumented migrants, i.e., those lacking any document relevant for this purpose. As will be explained below, the conditions governing their access to healthcare is contingent upon this distinction.

Regular migrants (i.e., authorized residents), asylum-seekers, and refugees, including people in their household, are granted access to health care in the same conditions as nationals. ${ }^{23}$ That includes benefiting from the full range of services available (emergency care, primary and secondary outpatient healthcare, hospitalization, ante, and post-natal care, HIV and other infectious diseases screening and treatment), usually by only paying moderating fees, ${ }^{24}$ but even those can be exempted in cases of economic difficulties attested by the social security services. Some services are provided for free (e.g., ante and post-natal care). In the case of asylum-seekers and

\footnotetext{
${ }^{22}$ Article 4(1)(c) of Decree-Law 113/2011, of November 29 (last amended by Law 84/2019, of September 3).

${ }^{23}$ See Article 83(1)(2) of Foreigners' Act (Law 23/2007, July 4, last amended by Law 28/2019, March 29) the Order 25 360/2001, December 12, Circular Informativa 12/DQS/DMD, May 7, 2009, of the DirectorateGeneral of Health. Regarding asylum-seekers and international protection applicants see Article 52 of the Asylum Act.

${ }^{24}$ Most national health services are subject to user charges usually subject to extensive exemptions. The depth of coverage is lower for pharmaceuticals. For more details see Augusto et al. 2017:62-66.
} 
refugees, as well as their family members, there is a full exemption from moderating fees. $^{25}$

Third-country irregular migrants who possess an official declaration stating that they reside in Portugal for over 90 days, are granted access to all medical care available to national citizens. ${ }^{26}$ This formal declaration entails proof of residency and is issued by the local borough council that may demand two oral testimonies to validate the certification. ${ }^{27}$ In these cases, foreigners pay the same moderating fees applicable to nationals.

If the 90-day requirement is not met, or foreigners are unable to prove it, they are still entitled to access healthcare. Still, they might be subject to paying full costs, except for emergency and vital care, treatment for contagious diseases that present public health risks (such as HIV or tuberculosis, or at the present moment COVID-19), ante and post-natal care, vaccination, and family planning, which are subject to the same moderating fees applicable to nationals (Direção-Geral de Saúde 2009). The national health service supports these services. The other healthcare services may be subject to the condition that the individual pays the full cost. That includes primary and secondary care. Irregular migrants will only be exempt from these payments if they can document a precarious economic condition, as demonstrated by the Social Security services (Direção-Geral de Saúde 2009). In principle, the authorities do not have access to the patients' medical records and health professionals are subject to a code of confidentiality (PICUM 2007). According to Article 139 of the Statute of the Portuguese Medical Association, approved by Law No. 117/2015 of 31 August, Doctors are forbidden from revealing all facts which have become known to the doctor during the course of carrying out, or because of, their profession. Still there is the fear that revealing their presence in the Portuguese territory in such open manner might lead to a risk of deportation.

That is why, for the Portuguese case, it is relevant to distinguish between migrants in a precarious situation who hold a valid document (either a permit or asylum request or proof of residency) and those who lack any document relevant for this purpose. The conditions to access healthcare vary in accordance with these criteria.

In the case of migrants who do not hold an official declaration stating that they reside in Portugal for over 90 days, healthcare services shall be provided in accordance with the needs, and migrants shall afterward be referred to a National Immigrant Support Centre or to a Local Immigrant Integration Support Centre to proceed with the regularization process.

There are some special cases of mainstreaming the right to health of children and other vulnerable groups into the implementation of national health strategies. That is the case of underage children residing in Portugal, who are granted full access to healthcare in the same conditions as nationals even if they fall under the category of irregular migrants, ${ }^{28}$ and individuals in situations of family reunion, who may also benefit from those favorable conditions if they demonstrate that someone in their household pays social security contributions.

\footnotetext{
${ }^{25}$ See Article 4(1)(n) of Decree-Law 113/2011, November 29, last amended by Law 84/2019, September 3.

${ }^{26}$ Order of the Ministry of Health no 25350/2001.

${ }^{27}$ On the difficulties experienced by migrants in obtaining these certificates see Serviço Jesuíta aos Refugiados (2019), at 9.

${ }^{28}$ Decree-Law 67/2004, of March 24.
} 


\section{Critical Implementation of the Normative and Regulatory Framework}

Implementation of this disperse and complex framework raises obstacles to effective access to healthcare services by irregular and undocumented migrants. Apart from the general difficulties caused by linguistic and cultural barriers, some of the reported obstacles concern software limitations when the individual user number is absent, leading to impediments to perform certain medical acts or medical examinations or to exempt costs. There are also cases of refusal from private providers integrated in the national health service to allocate costs following the applicable regulatory framework and even denial of access to migrants, including in the case of children who benefit from a full assimilation clause for healthcare (Entidade Reguladora da Saúde 2015, pp. 61-62). There are reported cases of children being denied emergency healthcare or only being granted access after parents have paid the total cost. ${ }^{29}$ These factual examples show that, despite the generous Portuguese legal framing, in some cases, even the minimum core of the right to health according to the standard developed by the CESCR and $\mathrm{CRC}$, which includes primary health care services, is not guaranteed in what regards irregular migrants and their children. Implementation of the right the health thus sometimes fails to abide not only with the national and more demanding standard of protection but also with the minimum core of the right as developed by the CESCR and the CRC.

Bureaucratic limitations also prevent the registration and monitoring of migrants, particularly irregular migrants, as legally required. ${ }^{30}$ Without a comprehensive and structured registration of this population, there is a considerable lack of information and data, which jeopardizes the design of public policies aimed at improving better access of this vulnerable population to healthcare.

This deficit at the level of implementation of the right to health evidences a gap between the normative protection afforded by the Portuguese legal and regulatory framework and the factual reality. It is unfortunately widely recognized that severe legal and institutional obstacles persist and prevent the effective enjoyment of fundamental rights by foreigners (Serviço Jesuíta aos Refugiados 2019).

Against this backdrop, it is easier to understand and put into context the political initiative to regularize certain migrants during the Covid-19 outbreak. The temporary regularization serves as a tool to bridge the gap between normative protection and policy and the practical realization of the irregular migrants' right to access healthcare.

\section{Temporary Regularization of Migrants During the Covid-19 Pandemic}

The first cases of Covid-19 in Portugal were announced on March 2, 2020. In the early stage, the Government, acting under the existing framework, adopted measures aimed at reducing social contact and preventing a sharp increase in infections. These measures included the closure of all schools, with effect on March 16, and restricted access to restaurants and bars. The provision of activity through telework was imposed, provided

\footnotetext{
${ }^{29}$ See the decisions issued by Entidade Reguladora da Saúde on September 19, 2019 and August 30, 2019, available at https://www.ers.pt/media/2935/ers_84_2018.pdf and https://www.ers.pt/media/2934/ers_132_ 2018.pdf.

${ }^{30}$ See Circular Informativa 001/2010/AICSTF, September 14, 2010, available at: http://www2.acss.minsaude.pt/Portals/0/CINFOR_001_2010_AICSTF.pdf.
} 
that it was compatible with the functions performed and upon the determination by the employer or request by the employee.

On March 18, the President of the Republic declared a state of emergency that allows for temporary and limited suspensions of fundamental rights (Raposo 2020b; Violante and Lanceiro 2020).

Broad partial suspensions of human rights have been enforced, particularly concerning the right to travel, the right to private property, and the freedom of enterprise, as entire sectors have been forced to shut down. The Government enforced a general confinement duty with stricter rules to infected people and risk groups, allowing the general population to leave home only if necessary, to work, shop for essential goods, or exercise.

However, the state of emergency also prompted legislative and political initiatives to foster the human rights of vulnerable categories of individuals, such as migrants and asylum-seekers and detainees ${ }^{31}$.

Regarding asylum-seekers and migrants, the Government decided to temporarily regularize those who had already submitted applications under the Immigration Act or the Asylum Act. ${ }^{32}$ The regularization was achieved through a fast-track process available to those migrants who, by March 18 (the date the state of emergency was initially declared $)^{33}$, had submitted their applications to the Immigration and Borders Office (SEF). ${ }^{34}$

The regularization was initially valid until June 30, 2020. However, as the pandemic evolved, the Government enacted further regulation extending the effects of the regularization period. According to Order No. 10944/2020 of 8 November, every foreign national with an application pending before SEF which has been submitted between March 18 and October 15, 2021, was deemed temporarily regular in national territory.

The regularization effects are valid during the appreciation and processing period of the procedure which remains suspended, thereby ensuring an equal treatment for foreigners. According to Decree-Law 87-A/2020, of October 15, the application documents are valid until 31 March 2021, and will continue to be accepted under the

\footnotetext{
31 To reduce the risk of contagion in prisons about 10 percent of inmates were granted early release following the implementation of Law 9/2020, April 10 (exceptional flexibilization scheme for the execution of penalties and acts of clemency in the context of the Covid-19 pandemic).

32 Respectively, Law 23/2007, July 4, last amended by Law 28/2019, March 29 and Law 27/2008, June 30, last amended by Law 26/2014, May 5 .

33 The first state of emergency was declared on March 18, 2020 and renewed three times until May 2. The second state of emergency was declared on November 9, 2020 and has been renewed three times until January 7, 2021. It is expected to be renewed further. Renewals are subject to a maximum duration of 15 days.

${ }^{34}$ Order 3863-B/2020, March 27, which determines the management of services provided and scheduling of appointments so as to safeguard unequivocally the rights of all foreign citizens with pending cases before the Immigration and Borders Service, in the context of Covid-19. See the official practical guide in English available at: https://www.acm.gov.pt/documents/10181/759579/Guia+Pratico ENG.pdf/bb5b1106-20b141d4-9841-fc94067ef8a5. For a commentary in Italian see Emellin de Oliveira, "Portogallo. Il Covid-19 fa regolarizzare i migrant", at: https://volerelaluna.it/mondo/2020/04/08/portogallo-il-covid-19-fa-regolarizzarei-migranti/?fbclid=IwAR26ut-xFoIA0yDypORblEXlrJP6Ajg-vYBsyf4fBg5Q6uf3J1LpqX6sgKQ. A nonofficial English version of Order 3863-B/2020, March 27, can be accessed here: http:// novarefugeelegalclinic.cedis.fd.unl.pt/?blog_post=despacho-n-o-3863-b-2020-de-27-de-marco\&fbclid= IwAR1OxLqL-bBc02c4xYViUn0APTIPBKTKa4xLaDb76q6P8HAnfXLiPM5Ee4s.
} 
same conditions after 31 March 2021, as long as the applicant submits supporting evidence of the scheduling for the corresponding renewal.

Proof of a pending case at SEF is, therefore, an essential condition to benefit from this mechanism. That proof may either consist of a receipt of the booking appointment, the appointment itself, or a document proving an asylum request. These documents constitute valid evidence of the regularity of the foreigner's stay on national territory and must be accepted as such by public entities. According to the Government, this measure applied to 130,000 migrants who had pending requests on March $18 .^{35}$

This is a full (temporary) regularization for all relevant effects. Foreign nationals in that situation have guaranteed access to every public service, such as inscription and access to the national health service, as well as access to social benefits. They can also access rental and employment contracts, open bank accounts, and hire essential public services.

Furthermore, visa and residence permits expired after February 24 are also considered proof of legal stay, as their validity is extended until March 21, 2021. ${ }^{36}$ A similar remedy was already entailed in the Foreigners' Act whereby, in case of temporary residence permit, the receipt which demonstrates that a renewal request has been submitted produces the same effects as the valid permit during 60 days, subject to renewal. $^{37}$

Through this fast-track temporary regularization process, these individuals are afforded the same protection as nationals and other beneficiaries of the national health service regarding access to healthcare and pharmaceutical assistance. This means that they can get the same medical care under the same conditions, being subject to payment of moderating fees and not any costs. These fees can be exempted in case of economic insufficiency. Fees for diagnosis and treatments under Covid-19 have been exempted from all the beneficiaries of the national health service. ${ }^{38}$

It is crucial to take stock of the pressure SEF counters have been under since the latest amendments to the Foreigners' Act. ${ }^{39}$ According to an NGO report, the greatest obstacle to the integration of foreigners is the disruption in the SEF's capacity to process all the requests. During 2019, appointments were cancelled from August onwards, as the administrative services were unable to manage all the bookings and appointments requested thus far. The legal deadlines have quadrupled, and there is the notice of asylum requests pending for over 2 years without any evidence assessment act being conducted (the maximum legal period is 9 months). Work permit requests are

\footnotetext{
$\overline{35} \mathrm{https} / / / \mathrm{rr}$.sapo.pt/2020/05/05/pais/coronavirus-mai-confirma-que-130-mil-imigrantes-ficaramprovisoriamente-com-situacao-regularizada/noticia/191814/?fbclid= IwAR1vhIddSssT75LmOjLlcI2fjichcMKDv2MVu0E94IietLV-FZG2kgqganI

${ }^{36}$ According to Article 16 of Decree-Law 10-A/2020, of March 13, last amended by Decree-Law 87-A/2020, of October 15.

${ }^{37}$ See Article 78(7), of Law 23/2007, of July 4 (last amended by Law 28/2019 of March 29), on the Rules of Entry, Permanent Residency, Leaving and Expulsion of Foreign Nationals from Portuguese Territory.

${ }^{38}$ Article 6-A of Decree-Law 10-A/2020, of March 13, as amended by Article 3 of Decree-Law 12-A/2020, of April 6.

${ }^{39}$ Particularly the ones introduced by Law 59/2017, of July 31. This act loosened the conditions for regularization, eliminating the need of a legal stay in the national territory, and reduced the cases where expulsion of foreigners is permitted. The Ombudsperson Report for 2018 underpinned the increase in SEF's activity and expressed concern with the ability to respond in due time to all the regularization requests, suggesting the strengthening of the administration's capacity to deal with the growing demand. See Relatório à Assembleia da República - 2018, available at: http://www.provedor-jus.pt/?idc=16\&idi=17973.
} 
taking more than 1 year (the maximum deadline is 9 months), and renewal processes, which are subject to a maximum deadline of 60 days, take more than 3 months to complete (Serviço Jesuíta aos Refugiados 2019). As the documents provided by SEF are a necessary condition for the enjoyment of basic rights by foreigners, this is a threatening situation that deprives these individuals from access to the right to health and other social entitlements, such as the right to social security and education.

A clear advantage is that the fast-track regularization procedure allowed to cope with the drastic reduction of administrative services with no detrimental consequences to the interests of migrants who had initiated a regularization process. The offices of SEF were shut down, and only essential services were guaranteed. The appointments at SEF have been suspended and were rescheduled from July 1 onwards. Only urgent cases were scheduled during this period, subject to the decision of regional directors. By preventing personal appointments during the peak of the pandemic, this measure has the potential to reduce health risks for both SEF workers and migrants, without reducing the latter's right to an adequate analysis of their application.

Moreover, based on this measure, access to healthcare has been granted on a generous basis: it not only gives unrestricted access but also secures that it is processed under the most favorable economic conditions. In fact, not every migrant is assimilated to nationals when it comes to bearing the costs of medical care. Situations falling outside the broad definition of "dangers or threats to public health" may trigger the payment of costs (and not just moderating fees) for migrants who do not hold a valid residency permit or proof of residency and are not registered at the Social Security offices. The regularization has granted these migrants not only unrestricted access but also that it will be subject only to the payment of moderating fees, which can be exempted in cases of economic insufficiency. Importantly, it has simplified the process for obtaining their user number, an essential condition to access the national health service.

The regularization measure thus had the effect of putting these migrants under a comprehensive protective umbrella granting access to the national health service on the most favorable economic conditions, both for situations raising public health concerns and for any other health condition, even if prominently relevant at an individual or private level. Since Covid-19 has put the health services under the risk of collapse, this comprehensive approach underscores the humanitarian significance of the Portuguese temporary regularization option.

The regularization measure has been criticized by migrants' associations for not being sufficiently inclusive, as all the individuals that had not initiated a process near SEF will fall out of the assimilation regime. ${ }^{40}$

This means that these individuals will be subject to the general rules governing the access of undocumented migrants to the national health service. As referred supra, it remains to be determined how, under the new Basic Law for Health, that access is to be granted and under which conditions. As the former reciprocity clause was abolished, and express reference is made to the inclusion of every migrant in the right to health under the same conditions shared by nationals, the regulatory framework should be subject to clarification in order to provide legal security both to migrants and to

\footnotetext{
$\overline{40}$ https://www.dn.pt/pais/imigrantes-sem-autorizacao-de-residencia-e-a-trabalhar-na-agricultura-preocupamassociacoes-11991333.html.
} 
healthcare units regarding the terms for access and the distribution and allocation of financial costs therein. It is important to notice that a very recent guideline issued by the Health Directorate-General determined that under the new Basic Health Law "no administrative barriers on access to the national health service are allowed, and migrants and refugees, regardless of their statute, either documented or undocumented, have the right to access the national health service under the same conditions as national, for reasons of protection of public health" (Direção-Geral de Saúde 2020). However, regarding the conditions for access to the national health service, this document refers to the regularization regime under Order 3863-B/2020, failing to address the vacuum in which truly undocumented migrants have been placed.

The fast-track regularization procedure thus represents the Government's acknowledgment of the vulnerable situation that these individuals face in times of a pandemic crisis and the attempt to remedy it, albeit only provisionally. Although it should be praised for the recognition of irregular migrants' condition and rights, it fails to include genuine undocumented migrants. Considering that under the ordinary regime, truly undocumented migrants already experience significant obstacles in accessing basic rights that the constitutional and legal framework uncontestably recognizes as several NGOs and regulatory agencies report, the regularization initiative failed to take the State's duty to protect these vulnerable individuals under a pandemic crisis to its full extent.

The practical effect of the regularization, regarding access to health care, is to equate the proof of pending applications near SEF to proof of residency in the national territory for more than 90 days. Irregular migrants who can document this criterium are already granted health protection, including entitlements and conditions, under the same framework applicable to nationals. What this regularization fails to address is the situation of irregular migrants who do not hold any valid document: neither a document that proves a pending request near SEF nor a valid proof of residency. And, as we have seen, it is this particular category of migrants who, under regular times, are afforded less protection concerning their right to health.

\section{An Assessment of the Possible Solutions to Ensure Health Care During Pandemics}

The protection of everyone, nationals, and migrants, legally and illegally staying, is a priority during the COVID-19 pandemic (Subcommittee on Prevention of Torture and Other Cruel, Inhuman, or Degrading Treatment or Punishment 2020). The imperative need for this objective is based not only on the protection of migrants themselves but also on the protection of the entire community. It is both a matter of individual rights and public health (Beyrer 2003). Thus, at least medical assistance related to COVID19 - screening and testing programs, treatments, vaccines when available — shall be provided to irregular migrants in the same terms as for legal residents and nationals. ${ }^{41}$ Open access shall be complemented by policies of multicultural and multilingual communication to address their specificities (De Vito et al. 2016).

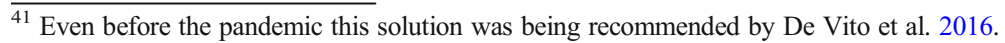


Nonetheless, to simply grant migrants in irregular situation full access to healthcare is not enough. Chances are these individuals refrain from using the health services made available to them unless there is a guarantee they will not be reported to immigration services and eventually deported. This guarantee can be achieved in two different ways, each one with its pros and cons.

One is by creating a firewall between healthcare delivery and immigration services (Platform for International Cooperation on Undocumented Migrants 2015; Van Durme 2017), in such a way that the health services are not obliged to report the illegal status of migrants (actually, they must be prevented from doing so). Doctors, including public officers, shall be exempted from reporting irregular stays, even if they constitute a crime. It is crucial to ensure that migrants in irregular situation can safely look for medical assistance without fear of being deported. One might think this solution is difficult to sustain during a pandemic since the very nature of infectious diseases imposes the disclosure of information between the different state departments. Nonetheless, the legal status of the person is not a piece of relevant information in light of the aimed purpose, that is, the control of the health crisis. Thus, it is possible to create a system where data is transmitted between state authorities, but only including data necessary to control the disease (the patient's identification, the way to contact the person, his/her location, the exact state of health), disregarding the legal framework of his/her staying in the country. Moreover, there is no reason for this mechanism to be temporarily limited to pandemics. Apart from a health crisis and infectiouscontagious diseases, migrants in irregular situation should be provided with medical assistance from the national health service (even if not always on equal footing with residents) being assured that they will not be subject to persecution by the immigration services.

The other option is to regularize the situation of these migrants during the pandemic, that is, for a limited period, as Portugal did. ${ }^{42}$ Under this option, migrants in irregular situation are equated to regular migrants, thus having all the benefits provided to the latter, including in what regards healthcare. Usually, regular migrants receive the same benefits concerning healthcare provision as nationals, so, ultimately, this mechanism might equate migrants in irregular situation to nationals.

When compared with the first option, the temporary regularization has the advantage of a broader scope. The firewall solution guarantees secrecy on their information but does not grant access to every single service provided by the national health service (i.e., at no cost or at a minimum cost), but only to the services offered to people in their irregular situations, which might be a very restricted range (eventually, only the ones related with the pandemic itself).

In contrast, the regularization solution opens to migrants in irregular situation every health service provided to regular migrants (eventually, even to nationals), most likely a wide range of services. Moreover, it normally extends protection to other domains besides healthcare: social benefits, labor, education. However, it might have a downside related to the post-pandemic. The temporary regularization of migrants is, as indicated by its designation, provisional. After the control of the health crisis, their

\footnotetext{
$\overline{{ }^{22}}$ Temporary resident permits for the ones afflicted by infectious diseases has been suggested in the past (De Vito et al. 2016).
} 
status will return to its previous situation, and while some of them might already be in the process of becoming regularized, others might be living in the shadow. ${ }^{43}$ If information is allowed to freely circulate among state departments, a visit to the doctor during this temporary period might lead to future investigations on their legal status and, ultimately, to deportation after the end of the temporary regularization period. Therefore, the protection afforded by this solution is restricted to the health crisis period. In contrast, the solution of banning the communication of data about migrants in irregular situation has the advantage of providing more continual protection since it is not limited to the period of the pandemic. This mechanism can be enforced every time migrants in irregular situation look for health assistance (even though the services provided to them by the national health service vary across jurisdictions, they might include some other types of medical care besides infectious diseases).

These two solutions are not mutually exclusive, and, in a perfect scenario, they would work together: a permanent ban on the circulation of information, reinforced with a temporary regularization during the health crisis.

Whatever solution is selected to handle the right to health of migrants in irregular situation during a pandemic, it should be one quickly implemented as soon as the first indications of a health crisis appear. Thus, it should be discussed and planned before the actual health crisis arises (Rothstein and Coughlin 2019).

\section{Concluding Notes}

This paper states that under international human rights law, States have the obligation to provide health care to migrants in irregular situation, ${ }^{44}$ even though the exact content of that obligation is not clear. After establishing such a duty, the paper discusses the various forms to comply with that obligation. The paper uses Portugal as a case study due to the innovative legal solution enacted by Portuguese lawmakers during the pandemic. Despite being widely acclaimed, it does have some loopholes, which only shows how challenging it is to find a legal mechanism that allows migrants to receive healthcare, but at the same time protects them from harmful decisions taken by the immigration services.

Based on the Portuguese experience, the paper highlights two solutions considered the most adequate to achieve both aims (which can operate simultaneously): a temporary regularization and a firewall between immigration services and healthcare services. Each jurisdiction has its own particularities, but these solutions - eventually with some adaptations - are generally workable everywhere and in compliance with human rights standards.

Acknowledgements We are thankful to Professor Anuscheh Farahat and Dr. Kevin Fredy Hinterberger for their valuable comments and suggestions.

\footnotetext{
$\overline{43}$ The Portuguese solution is only applicable to the ones who have previously started the regularization procedure, but hypothetically this mechanism could cover also the ones that have not (as it has been claimed by some immigrant associations in Portugal).

${ }^{44}$ The same conclusion might be inferred from national regulations, but the paper focused on international law.
} 
Funding This work was supported by the University of Macau Multi-Year Research Grant MYRG201500008-FLL and by the German Research Foundation/Deusche Forshungsgemeinschaft (DFG) in the framework of the Emmy Noether-Project on "Transnational Solidarity Conflicts."

\section{Declarations}

Conflict of Interest The authors declare no competing interests.

\section{References}

Accornero G, Harb M, Magalhães AF et al (2020). 'Stay home without a home': Report from a webinar on the right to housing in Covid-19 lockdown times. Radical Housing Journal 2(1): 197-201.

Angeleri S (2017). The impact of the economic crisis on the right to health of irregular migrants, as reflected in the jurisprudence of the UN Committee on Economic, Social and Cultural Rights. European Journal of Migration and Law 19: 165-190.

ANSA (2020). Coronavirus in Italy: CPRs Ordered to Monitor Migrants' Health, InfoMigrants, 30 March 2020, [online]. Available: https:/www.infomigrants.net/en/post/23755/coronavirus-in-italy-cprsordered-to-monitor-migrants-health. Accessed on 2 June 2020.

Beyrer C (2003) Public health, human rights, and the beneficence of states. Human Rights Review 5:28-33. https://doi.org/10.1007/s12142-003-1002-0

Canotilho, JJG, Moreira V (2007) Constituição da República Portuguesa Anotada. Coimbra Editora, Coimbra.

Čelkis P, Venckienè E (2014) Relationship between the right to dignity and the right to healthcare. International Journal of Arts and Commerce 3(5):166-176.

Chetail V (2019) International Migration Law. Oxford University Press, US.

Committee on Economic, Social and Cultural Rights (2000) General Comment No 14: The Right to the Highest Attainable Standard of Health, UN DocE/C/12/2000/4, 11 August 2000.

Corscadden L, Levesque JF, Lewis V et al (2018). Factors associated with multiple barriers to access to primary care: an international analysis. Int J Equity Health 17(28). https://doi.org/10.1186/s12939-0180740-1

Council of Europe (2020). Commissioner calls for release of immigration detainees while Covid-19 crisis continues. Statement, 26 March. https:/www.coe.int/en/web/commissioner/-/commissioner-calls-forrelease-of-immigration-detainees-while-covid-19-crisis-continues. Accessed on 12 June 2020.

D'ignoti S (2020). How coronavirus hits migrants and asylum seekers in Italy. The New Humanitarian, 16 March. http://www.thenewhumanitarian.org/news/2020/03/16/italy-coronavirus-migrants-asylumseekers. Accessed on 14 May 2020.

Da Lomba S (2014) Vulnerability, irregular migrants' health-related rights and the European Court of Human Rights. European Journal of Health Law 21:339-364.

De Vito E, De Waure C, Specchia ML et al. (2016) Are undocumented migrants' entitlements and barriers to healthcare a public health challenge for the European Union? Public Health Review, 37(13). https://doi. org/10.1186/s40985-016-0026-3.

De Vito E, De Waure C, Specchia ML, Ricciardi W (2015) Public health aspects of migrant health: a review of the evidence on health status for undocumented migrants in the European Region. Copenhagen: WHO Regional Office for Europe.

Department of Health (2017) Making a fair contribution: government response to the consultation on the extension of charging overseas visitors and migrants using the NHS in England. https://assets.publishing. service.gov.uk/government/uploads/system/uploads/attachment_data/file/590027/Cons_Response_cost_ recovery.pdf. Accessed on 16 December 2020.

Desmond A (2016) The development of a common EU migration policy and the rights of irregular migrants: A progress narrative? Human Rights Law Review 16(2):247-272.

Devakumar D, Shannon G, Bhopal SS, Abubakar I (2020) Racism and discrimination in COVID-19 responses. The Lancet 395(10231):1194.

Dewhurst E (2013) Models of protection of the right of irregular immigrants to back pay: The impact of the interconnection between immigration law and labor law. Comparative Labor Law and Policy Journal 35(2):101-130.

Dias S, Gama A, Cortes M, Sousa B (2011) Healthcare-seeking patterns among immigrants in Portugal. Health and Social Care in the Community 19(5): 514-521. 
Direção-Geral de Saúde (2009) Circular Informativa 12/DQS/DMD. https:/www.dgs.pt/directrizes-da-dgs/ orientacoes-e-circulares-informativas/circular-informativa-n-12dqsdmd-de-07052009-pdf.aspx. Accessed on 16 June 2020.

Direção-Geral de Saúde (2013) Manual de Acolhimento no Acesso ao Sistema de Saúde de Cidadãos Estrangeiros. https:/www.dgs.pt/em-destaque/manual-de-acolhimento-no-acesso-ao-sistema-de-saudede-cidadaos-estrangeiros.aspx. Accessed on 16 June 2020.

Direção-Geral de Saúde (2020) Informação 10/2020, Covid-19: Fase de mitigação - Migrantes e Refugiados. https://www.dgs.pt/normas-orientacoes-e-informacoes/informacoes/informacao-n-0102020-de08052020-pdf.aspx. Accessed on 16 June 2020.

Entidade Reguladora da Saúde (2015) Acesso a cuidados de saúde por imigrantes. https://www.ers.pt/uploads/ writer_file/document/1480/Estudo_ERS_-_Acesso_a_Cuidados_de_Saude_por_Imigrantes_v2_.pdf. Accessed on 16 June 2020.

European Commission (2009) Communication from the Commission to the European Parliament, the Council, the European Economic and Social Committee and the Committee of the Regions, Solidarity in Health: Reducing Health Inequalities in the EU. http://eur-lex.europa.eu/legal-content/EN/TXT/?qid= 1396946539740\&uri=CELEX:52009DC0567 Assessed on 14 May 2020.

European Committee for the Prevention of Torture and Inhuman or Degrading Treatment or Punishment (2020) Statement of principles relating to the treatment of persons deprived of their liberty in the context of the coronavirus disease (COVID-19) pandemic, CPT/Inf(2020)13. https://rm.coe.int/16809cfa4b. Accessed on 20 May 2020.

European Parliament (2011) Resolution of 8 March 2011 on reducing health inequalities in the EU, 2010/2089(INI). http://eur-lex.europa.eu/LexUriServ/LexUriServ.do?uri=OJ:C:2012:199E:0025:0036: EN:PDF. Accessed on 23 July 2020.

European Union Agency for Fundamental Rights (2011) Fundamental rights of migrants in an irregular situation in the European Union Comparative report. Publications Office of the European Union, Luxembourg.

European Union Agency for Fundamental Rights (2020) Fundamental rights of refugees, asylum applicants and migrants at the European borders. https://ra.europa.eu/sites/default/files/fra_uploads/fra-coe-2020european-law-land-borders_en.pdf. Assessed in 13 July 2020

Freitas, Tiago Fidalgo (2009) Portuguese migration law. A constitutional and administrative overview. European Review of Public Law 21(1):345-401.

Ghebreyesus TA (2017) All roads lead to universal health coverage. The Lancet 5(9):E839-E840. https://doi. org/10.1016/S2214-109X(17)30295-4

Gil AR (2017) Imigração e direitos humanos. Petrony, Lisboa.

Gottlieb N, Trummer U, Davidovitch N et al. (2020) Economic arguments in migrant health policymaking: proposing a research agenda. Global Health 16(113). https://doi.org/10.1186/s12992-020-00642-8

Guadagno L (2020) Migrants and the COVID-19 pandemic: An initial analysis. International Organization for Migration, https://publications.iom.int/system/files/pdf/mrs-60.pdf. Accessed on 11 May 2020.

Guild E (2004) Who is an Irregular Migrant? In: B Bogusz et al. (eds) Irregular Migration and Human Rights: Theoretical, European and International Perspectives, Immigration and Asylum Law and Policy in Europe. Martinus Nijhoff Publishers, Leiden, pp 3-28.

Hayden P (2012) The human right to health and the struggle for recognition. Review of International Studies 38:569-588.

Hinterberger KF (2019) An EU regularization directive. An effective solution to the enforcement deficit in returning irregularly staying migrants. Maastricht Journal of European and Comparative Law 26(6):736769.

Inter-American Court of Human Rights (2003) Advisory opinion OC-18/03, juridical condition and rights of undocumented migrants, OC-18/03, 17 September 2003. https://www.refworld.org/ cases,IACRTHR,4f59d1352.html. Accessed on 3 July 2020.

International Organization for Migration (2016) IML Information Note on International Standards on Immigration Detention and Non-Custodial Measures. International Migration Law Unit (IML). https:// www.iom.int/sites/default/files/our_work/ICP/IML/IML-Information-Note-Immigration-Detention-andNon-Custodial-Measures.pdf. Accessed on 9 June 2020.

International Organization for Migration (2019). World Migration Report 2020. [online]. Available: https:// www.iom.int/sites/default/files/our_work/ICP/IML/IML-Information-Note-Immigration-Detention-andNon-Custodial-Measures.pdf. Accessed on 9 May 2020.

Intensive Care National Audit \& Research Centre (2020) COVID-19 Report (2020). https://www.icnarc.org/ Our-Audit/Audits/Cmp/Reports [1 July 2020]. 
Jackson Y, Courvoisier DS, Duvoisin A, et al. (2019) Impact of legal status change on undocumented migrants' health and well-being (Parchemins): Protocol of a 4-year, prospective, mixedmethods study. BMJ Open 9:e028336. https://doi.org/10.1136/bmjopen-2018-028336

Kuehne A, Huschke S, Bullinger M (2015) Subjective health of undocumented migrants in Germany - a mixed methods approach. BMC Public Health 15:926.

Larking E (2016) Irregular immigrants in Australia and the United States - Rights, realities, and political mobilization. Journal of Human Rights 15(2): 189-207. https://doi.org/10.1080/14754835.2015.1032218

Liem A, Wang C, Wariyanti Y, Latkin CA, Hall BJ (2020) The neglected health of international migrant workers in the COVID-19 epidemic. The Lancet 7(4). https://doi.org/10.1016/S2215-0366(20)30076-6

Lorena A, Foulvia A (2016) Towards European modern societies with health systems that are able to add more years to life, but also to add more life to years. In: P Manolitzas, E Grigoroudis, NF Matsatsinis, D Yannacopoulos (eds) Effective Methods for Modern Healthcare Service Quality and Evaluation. Idea Group, Harrisburg, PA, United States, pp 228-255.

McHale J (2010) Fundamental rights and health care. In: E Mossialos, G Permanand, R Baeten, T Hervey (eds) Health Systems Governance in Europe: The Role of European Union Law and Policy. Cambridge University Press, Cambridge, pp 282-314.

Merlino M, and Parkin, J (2012) Fundamental and Human Rights Framework: Protecting Irregular Migrants in the EU, Centre for European Policy Study (CEPS). https://migration.etuc.org/en/docs en $/ 3 \%$ 20 Fundamental $\% 20$ and $\% 20$ Human $\% 20$ Rights $\% 20$ Framework_\%20Protecting\%20Irregular\% 20Migrants\%20in\%20the\%20EU.pdf

Migration Data Portal (2020) Migration data relevant for the COVID-19 pandemic, last update 7 May 2020. https://migrationdataportal.org/themes/migration-data-relevant-covid-19-pandemic Accessed on 8 June 2020.

Milne C (2016) Health tourism: what's the cost? Full Fact. https://fullfact.org/health/health-tourism-whatscost. Acceessed on 18 December 2020.

Office of the High Commissioner for Human Rights and World Health Organization. (2020) COVID-19: Focus on persons deprived of their liberty. interim guidance, inter-agency standing committee. https:// interagencystandingcommittee.org/system/files/2020-03/IASC\%20Interim\%20Guidance\%20on\% 20COVID-19\%20-\%20Focus\%20on\%20Persons \%20Deprived\%20of\%20Their\%20Liberty.pdf. Accessed on 11 June 2020.

Onarheim KH, Melberg A, Meier BM, Miljeteig I (2018) Towards universal health coverage: including undocumented migrants. BMJ Global Health 3:e001031.

Orrenius PM, Zavodny M (2016) Irregular Immigration in the European Union. European Policy Analysis 2: $1-20$.

Peroni L, Timmer A (2013) Vulnerable groups: The promise of an emerging concept in European Human Rights Convention law. International Journal of Constitutional Law 11(4):1056-1085.

PICUM - Platform for International Cooperation on Undocumented Migrants (2007) Access to Health Care for Undocumented Migrants in Europe. http://picum.org/Documents/Publi/2007/Access_to_Health_ Care_for_Undocumented_Migrants_in_Europe.pdf. Accessed on 1 January 2021

Platform for International Cooperation On Undocumented Migrants (2014) Access to Health care for Undocumented Migrants in Europe: The Key Role of Local and Regional Authorities. http:/picum.org/ picum.org/uploads/publication/PolicyBrief Local\%20and\%20Regional\%20Authorities AccessHealthCare_UndocumentedMigrants_Oct.2014.pdf. Accessed on 25 May 2020.

Platform for International Cooperation on Undocumented Migrants (2015) Undocumented Migrants and the Europe 2020 Strategy: Making Social Inclusion A Reality for All Migrants in Europe. http://picum.org/ wp-content/uploads/2017/11/UndocumentedMigrantsandEurope2020Strategy_EN.pdf. Accessed on 26 May 2020.

Poduval S, Howard N, Jones L, et al (2015) Experiences among undocumented migrants accessing primary care in the United Kingdom: a qualitative study. International Journal of Health Services 45:320-33.

Raghupathi V, Raghupathi W (2020). Healthcare Expenditure and Economic Performance: Insights From the United States Data. Frontiers in Public Health. https://doi.org/10.3389/fpubh.2020.00156

Raposo VL (2020a) The CJEU's ruling in the Novartis Farma case: Money, health and medicines. Maastricht Journal of European and Comparative Law 27(2):178-198.

Raposo VL (2020b). Portugal, Fighting Covid-19 in the Edge of Europe. BioLaw Journal/Rivista de Biodiritto. https://www.biodiritto.org/content/download/3890/45927/version/1/file/65+Raposo.pdf. Accessed on 16 July 2020.

Rothstein MA, Coughlin CN (2019) Ensuring compliance with quarantine by undocumented immigrants and other vulnerable groups: Public health versus politics. AJPH 109(9):1179-1183. 
Serviço de Estrangeiros e Fronteiras (2018) Relatório de Imigração, Fronteiras e Asilo. https://www.sef.pt/pt/ pages/conteudo-detalhe.aspx?nID=92. Accessed on 16 July 2020.

Serviço Jesuíta aos Refugiados (2019) Livro Branco sobre os Direitos dos Imigrantes e Refugiados em Portugal. http://www.jrsportugal.pt/wp-content/uploads/2019/12/Livro-Branco-Servi\%C3\%A7o-Jesu\% C3\%ADta-aos-Refugiados.pdf. Accessed on 16 July 2020.

Silva JP (2004) Direitos de Cidadania e Direito à Cidadania, Alto-Comissariado para a Imigração e Minorias Étnicas, Lisboa.

Silva JP (2010) Artigo 15. ․ In J Miranda, R Medeiros. Constituição Portuguesa Anotada. Coimbra Editora, Coimbra, pp 261-288.

Simões JA, Augusto GF, Fronteira I, Hernández-Quevedo C (2017) Portugal: Health System Review. Health Systems in Transition 19(1). https://www.euro.who.int/_data/assets/pdf_file/0007/337471/HiT-Portugal. pdf. Accessed on 16 July 2020.

Subcommittee on Prevention of Torture and Other Cruel, Inhuman or Degrading Treatment or Punishment (2020) Advice of the Subcommittee on Prevention of Torture to states parties and national preventive mechanisms relating to the coronavirus pandemic. https://www.ohchr.org/Documents/HRBodies/ OPCAT/AdviceStatePartiesCoronavirusPandemic2020.pdf. Accessed on 16 July 2020.

Terminsk B (2018) Economic migrants in international law and policy: Selected issues and challenges. Logos Verlag, Berlin.

Turner BS (2006) Vulnerability and Human Rights. The Pennsylvania State University Press, University Park.

United Nations (2014) The Economic, social and cultural rights of migrants in an irregular situation. https:// www.ohchr.org/Documents/Publications/HR-PUB-14-1 en.pdf. Accessed on 10 May 2020.

Van Durme C (2017) 'Firewall': A tool for safeguarding fundamental rights of undocumented migrants. Platform for International Cooperation on Undocumented Migrants. https://picum.org/firewall-toolsafeguarding-fundamental-rights-undocumented-migrants/. Accessed on 25 May 2020.

Violante T, Lanceiro R (2020) Coping with Covid-19 in Portugal: From Constitutional Normality to the State of Emergency. VerfBlog, 2020/4/12. https://verfassungsblog.de/coping-with-covid-19-in-portugal-fromconstitutional-normality-to-the-state-of-emergency/. Accessed on 16 July 2020.

World Health Organization (1946) Constitution of the World Health Organization. American Journal of Public Health 36(11): 1315-1323.

World Health Organization (2014a) Making fair choices on the path to universal health coverage: Final report of the WHO consultative group on equity and universal health coverage. World Health Organization: Geneva.

World Health Organization (2014b) The Case for Investing in Public Health. https://www.euro.who.int/ data/assets/pdf_file/0009/278073/Case-Investing-Public-Health.pdf. Assessed on 16 December 2020.

World Health Organization (2018a) Global Compact for Safe, Orderly and Regular Migration, https:// refugeesmigrants.un.org/sites/default/files/180713_agreed_outcome_global_compact_for_migration.pdf. Accessed on 10 July 2020.

World Health Organization (2018b). Health of refugee and migrant children (Copenhagen Ø, Denmark) [online]. Available: http://www.euro.who.int/_data/assets/pdf_file/0011/388361/tc-health-children-eng. pdf?ua $=1 \&$ crazycache $=1$. Accessed on 10 July 2020 .

Zaklaki RD (2019) Access to health care for illegal migrants: ethical implications of a new health policy in the UK. The British journal of general practice: the journal of the Royal College of General Practitioners 69(679): 56-57. https://doi.org/10.3399/bjgp19X700841

Publisher's Note Springer Nature remains neutral with regard to jurisdictional claims in published maps and institutional affiliations. 